Portland State University

PDXScholar

Urban Studies and Planning Faculty

Nohad A. Toulan School of Urban Studies and

Publications and Presentations

Planning

$6-2008$

\title{
Initiative for Bicycle and Pedestrian Innovation
}

Jennifer Dill

Portland State University, jdill@pdx.edu

Lynn Weigand

Portland State University

Follow this and additional works at: https://pdxscholar.library.pdx.edu/usp_fac

Part of the Social Welfare Commons, Transportation Commons, Urban Studies Commons, and the Urban Studies and Planning Commons

Let us know how access to this document benefits you.

\section{Citation Details}

Jennifer Dill and Lynn Weigand, Initiative for bicycle and pedestrian innovation. OTREC-TT-08-01 for the Oregon Transportation Research and Education Consortium (OTREC), June 2008. http://dx.doi.org/ $10.15760 /$ trec. 140

This Report is brought to you for free and open access. It has been accepted for inclusion in Urban Studies and Planning Faculty Publications and Presentations by an authorized administrator of PDXScholar. Please contact us if we can make this document more accessible: pdxscholar@pdx.edu. 


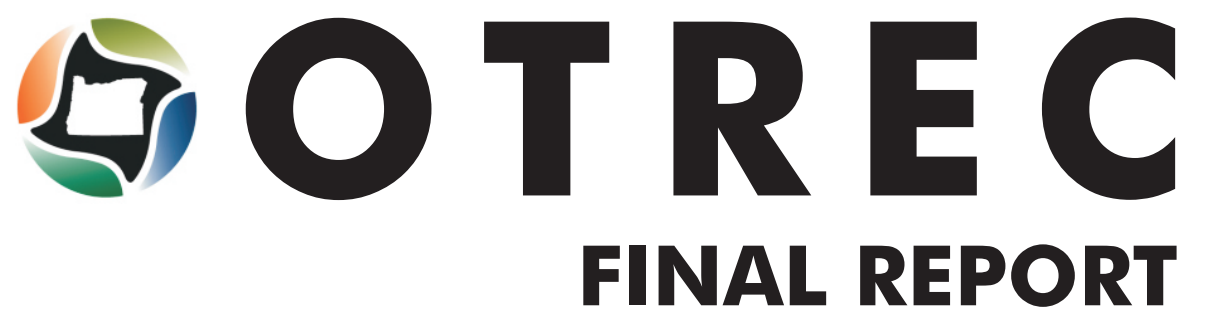

\section{Initiative for Bicycle and Pedestrian Innovation}

OTREC-TT-08-01 June 2008 


\title{
INITIATIVE FOR BICYCLE AND PEDESTRIAN INNOVATION
}

\section{Final Report}

\section{OTREC-TT-08-01}

\author{
by \\ Jennifer Dill, Ph.D. \\ Lynn Weigand, Ph.D. \\ Portland State University
}

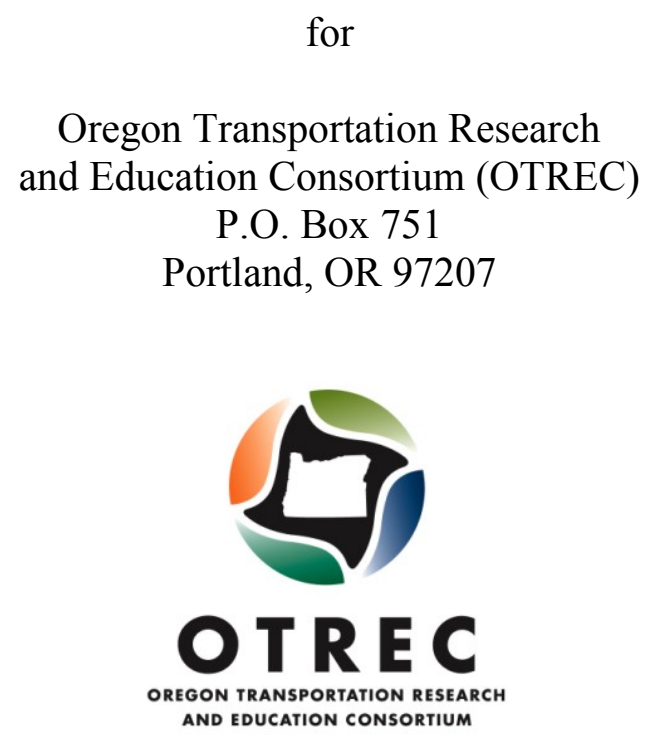

June 2008 



\begin{tabular}{|c|c|c|c|c|}
\hline \multicolumn{5}{|c|}{ Technical Report Documentation Page } \\
\hline $\begin{array}{l}\text { 1. Report No. } \\
\text { OTREC-TT-08-01 }\end{array}$ & \multicolumn{2}{|c|}{ 2. Government Accession No. } & \multicolumn{2}{|c|}{ 3. Recipient's Catalog No. } \\
\hline \multirow{2}{*}{\multicolumn{3}{|c|}{$\begin{array}{l}\text { 4. Title and Subtitle } \\
\text { Initiative for Bicycle and Pedestrian Innovation }\end{array}$}} & \multicolumn{2}{|l|}{$\begin{array}{l}\text { 5. Report Date } \\
\text { June } 2008\end{array}$} \\
\hline & & & \multicolumn{2}{|c|}{ 6. Performing Organization Code } \\
\hline \multicolumn{3}{|c|}{$\begin{array}{l}\text { 7. Author(s) } \\
\text { Jennifer Dill, Ph.D. and Lynn Weigand, Ph.D. }\end{array}$} & \multicolumn{2}{|c|}{ 8. Performing Organization Report No. } \\
\hline \multirow{2}{*}{\multicolumn{3}{|c|}{$\begin{array}{l}\text { 9. Performing Organization Name and Address } \\
\text { Portland State University } \\
\text { Toulan School of Urban Studies and Planning } \\
\text { Center for Transportation Studies } \\
\text { PO Box } 751 \text { - CTS } \\
\text { Portland, OR } 97207 \text { - } 0751\end{array}$}} & \multicolumn{2}{|c|}{ 10. Work Unit No. (TRAIS) } \\
\hline & & & \multicolumn{2}{|c|}{$\begin{array}{l}\text { 11. Contract or Grant No. } \\
\text { 2007-67 }\end{array}$} \\
\hline \multirow{2}{*}{\multicolumn{2}{|c|}{$\begin{array}{l}\text { 12. Sponsoring Agency Name and Address } \\
\text { Oregon Transportation Research } \\
\text { and Education Consortium (OTREC) } \\
\text { P.O. Box } 751 \\
\text { Portland, Oregon } 97207 \\
\end{array}$}} & & \multicolumn{2}{|c|}{$\begin{array}{l}\text { 13. Type of Report and Period Covered } \\
\text { Final Report } \\
\text { October } 1,2006 \text { - June } 30,2008\end{array}$} \\
\hline & & & \multicolumn{2}{|c|}{ 14. Sponsoring Agency Code } \\
\hline \multicolumn{5}{|l|}{ 15. Supplementary Notes } \\
\hline \multicolumn{5}{|c|}{$\begin{array}{l}\text { 16. Abstract } \\
\text { The Initiative for Bicycle and Pedestrian Innovation aims to advance the field of bicycle and pedestrian } \\
\text { transportation through four primary mechanisms: (1) developing and pursuing a collaborative research agenda that } \\
\text { more directly informs practice and and involves students through dissertation research and fellowships; (2) } \\
\text { translating relevant research into a format and language that is more useful to practitioners, and making that research } \\
\text { available through technology transfer; (3) developing more holistic approaches to the education and training of } \\
\text { planners and engineers; and (4) supporting community-based outreach and education, to promote awareness of } \\
\text { bicycle and pedestrian issues statewide and nationally. This proposal seeks one year of start-up funding for the } \\
\text { second objective (technology transfer). }\end{array}$} \\
\hline \multicolumn{5}{|c|}{$\begin{array}{l}\text { Key activities and outcomes from the OTREC funding for the Initiative's technology transfer activities include a } \\
\text { website clearinghouse for research and evidence-based tools that is accessible and meaningful and a series of four } \\
\text { white papers on areas of bicycle and pedestrian research that are directly relevant to professional practice and policy- } \\
\text { making. The website increases the availability of existing resources for use by practitioners. These resources } \\
\text { include an archive of weekly seminars sponsored by the Center for Transportation Studies at Portland State } \\
\text { University and digests of recent research by faculty and students at Portland State University, Oregon State } \\
\text { University and the University of Oregon. In addition, the website provides information on existing undergraduate } \\
\text { and graduate courses at all three universities, links to other academic and practice-based resources, and information } \\
\text { on upcoming and past professional development workshops. The white papers focused on topics that are new, cross- } \\
\text { disciplinary, and innovative, including: (1) the economic impacts of bicycle and pedestrian transportation; (2) the } \\
\text { effectiveness of Safe Routes to School programs and other approaches to creating safe, healthy transportation options } \\
\text { for children; (3) the effectiveness of intersection safety treatments for bicycle facilities; and (4) the mental health } \\
\text { benefits of bicycling and walking. }\end{array}$} \\
\hline \multicolumn{2}{|c|}{$\begin{array}{l}\text { 17. Key Words } \\
\text { Bicycle transportation, pedestrian transportation }\end{array}$} & \multicolumn{3}{|c|}{$\begin{array}{l}\text { 18. Distribution Statement } \\
\text { No restrictions. Copies available from OTREC: } \\
\text { www.otrec.us }\end{array}$} \\
\hline $\begin{array}{l}\text { 19. Security Classification (of this report) } \\
\text { Unclassified }\end{array}$ & & page) & No. of Pages 10 & 22. Price \\
\hline
\end{tabular}




\section{ACKNOWLEDGMENTS}

This project was funded by the Oregon Transportation Research and Education Consortium (OTREC).

\section{DISCLAIMER}

The contents of this report reflect the views of the authors, who are solely responsible for the facts and the accuracy of the material and information presented herein. This document is disseminated under the sponsorship of the U.S. Department of Transportation University Transportation Centers Program and the Oregon Transportation Research and Education Consortium (OTREC) in the interest of information exchange. The U.S. Government and OTREC assume no liability for the contents or use thereof. The contents do not necessarily reflect the official views of the U.S. Government or OTREC. This report does not constitute a standard, specification, or regulation. 


\section{TABLE OF CONTENTS}

\begin{tabular}{|c|c|}
\hline 1.0 & BACKGROUND AND OBJECTIVES \\
\hline 2.0 & PROJECT DESCRIPTION. \\
\hline 3.0 & OUTCOME AND RESULTS.. \\
\hline 0 & FURTHER ACTIVITIES .. \\
\hline & REFERENCES \\
\hline
\end{tabular}




\section{EXCUTIVE SUMMARY}

The Initiative for Bicycle and Pedestrian Innovation aims to advance the field of bicycle and pedestrian transportation through four primary mechanisms: (1) developing and pursuing a collaborative research agenda that more directly informs practice and and involves students through dissertation research and fellowships; (2) translating relevant research into a format and language that is more useful to practitioners, and making that research available through technology transfer; (3) developing more holistic approaches to the education and training of planners and engineers; and (4) supporting community-based outreach and education, to promote awareness of bicycle and pedestrian issues statewide and nationally. This proposal seeks one year of start-up funding for the second objective (technology transfer).

Key activities and outcomes from the OTREC funding for the Initiative's technology transfer activities include a website clearinghouse for research and evidence-based tools that is accessible and meaningful and a series of four white papers on areas of bicycle and pedestrian research that are directly relevant to professional practice and policy-making. The website increases the availability of existing resources for use by practitioners. These resources include an archive of weekly seminars sponsored by the Center for Transportation Studies at Portland State University and digests of recent research by faculty and students at Portland State University, Oregon State University and the University of Oregon. In addition, the website provides information on existing undergraduate and graduate courses at all three universities, links to other academic and practice-based resources, and information on upcoming and past professional development workshops. The white papers focused on topics that are new, cross-disciplinary, and innovative, including: (1) the economic impacts of bicycle and pedestrian transportation; (2) the effectiveness of Safe Routes to School programs and other approaches to creating safe, healthy transportation options for children; (3) the effectiveness of intersection safety treatments for bicycle facilities; and (4) the mental health benefits of bicycling and walking. 


\subsection{BACKGROUND AND OBJECTIVES}

To effectively advance bicycle and pedestrian transportation as mainstays of Oregon's transportation system, local governments and transportation agencies need the tools and information to be more effective and efficient in addressing our communities' needs. These needs have been expressed both locally and nationally. At the local level, it was these needs that initiated early discussions and provided the momentum for the development of the Initiative for Bicycle and Pedestrian Innovation (IBPI) at Portland State University. Nationally, these needs are reflected in a recent Ten-Year Status Report on the National Bicycling and Walking Study (FHWA, 2004). This study identifies areas in need of further attention. For example, one area is "better documentation of bicycling and walking activity," including the development of more accurate and consistent data collection methods, as well as improved documentation of the impact of bicycle and pedestrian investments on health and quality of life indicators.

These needs are reflected in the types of questions faced by local agencies in planning and designing transportation facilities. For example, how do decision-makers, engineers and planners know what types of pedestrian and bicycle projects will be most effective in improving livability? Can bicycle boulevards encourage more people to bike instead of drive? How can neighborhoods be designed so that older adults and children can safely cross the street? How can planners conduct more accurate and consistent counts of bicycle and pedestrian activity?

By bringing together researchers and practitioners through its technology transfer activities, IBPI is actively working to inform practice by communicating research findings to practitioners in ways that are useful and accessible. IBPI provides a mechanism for collaboration and knowledge sharing with researchers and professionals in national and international communities. It is a multi-campus partnership between Portland State University, the University of Oregon, and Oregon State University. The activities funded by this OTREC grant have given IBPI a solid foundation in its work to advance research and practice on bicycle and pedestrian transportation by serving as a resource for information and conducting relevant research that is relevant and accessible to practitioners. 


\subsection{PROJECT DESCRIPTION}

As a result of this OTREC-funded project, the Initiative for Bicycle and Pedestrian Innovation (IBPI) now serves as a clearinghouse for bicycle and pedestrian research and evidence-based tools, and a coordinating body for collaborative projects and research aimed at advancing bicycle and pedestrian transportation. These activities further the goal of equipping current professionals, students (future professionals), and decision makers with the knowledge needed to increase the safety and mode share for bicycle and pedestrian transportation.

\section{Website}

The primary mechanism for technology transfer is IBPI's website (http://ibpi.usp.pdx.edu). This website disseminates research and evidence-based tools aimed at advancing the field of bicycle and pedestrian transportation in a way that is accessible and useful to practitioners. Initial work on the website included a review of existing practice and research sites that provide information on walking and bicycling research, such as the National Center on Walking and Bicycling, The Association of Pedestrian and Bicycle Professionals, the Pedestrian and Bicycle Information Center, the University of Davis Sustainable Transportation Center and America Walks, This work provided a base to develop an inventory of available resources and identify the gaps that IBPI's site could fill. In addition, this review helped identify electronic resources and links to provide on IBPI's website, and places to publicize the resources available through IBPI. The website features a number of resources that are useful to both practitioners and scholars which are described below.

\section{Center for Transportation Studies Weekly Seminars}

The Center for Transportation Studies has a weekly seminar that is archived on the web and available as streamed media and downloadable files. There are many excellent seminars on pedestrian and bicycle topics available and several new seminars offered each quarter. IBPI has packaged and organized these by category at http://ibpi.usp.pdx.edu/seminarsummaries.php ad providing short descriptions of the seminars, so that practitioners can identify which ones will be useful. The summaries are also are linked to the CTS archive pages. This has increased the accessibility of the information from these seminars to professionals who cannot attend the seminars in person.

\section{Research Digests}

Investigators at all three of our partner institutions (Portland State University, Oregon State University and the University of Oregon) are conducting important research on bicycle and pedestrian transportation topics, but the results of their work are not easily available to practitioners. IBPI's website now features brief digests of relevant research that highlight the findings of interest to practice with links to the full research report, when available. This provides practitioners with a fast and easy way to stay abreast of current research that affects their work. 


\section{Student Projects}

IBPI's website also features summaries of student research and projects related to bicycling and walking. Quality student work can provide useful findings and outcomes that can inform practice, but is rarely, if ever, communicated beyond the classroom and instructor for which it is conducted. This feature of the website extends the reach of the knowledge generated by the students and supports student interest in bicycle and pedestrian transportation topics.

\section{Generating Ideas from Practitioners}

To encourage more interaction between research and practice, IBPI's website includes a place for practitioners to submit ideas for research and professional development topics. While this is a relatively new feature, we hope this will generate new ideas and the potential for research collaboration.

\section{Other Website Features}

IBPI's website also includes several other features to provide information and ideas. These include a resources page with links to other relevant organizations and agencies, listings of graduate and undergraduate courses offered at all three partner institutions, and links to the professional development workshops offered by IBPI.

\section{White Papers}

The IBPI Director and graduate students developed four white papers that reviewed national and international research on selected topics of high priority. The topics were selected through a process that began with a survey of local bicycle and pedestrian practitioners within Oregon. The survey was followed by a discussion with key stakeholders in practice and research to select topics. The topic areas were further refined by the Principal Investigator Dill and Dr. Hollie Lund based on their knowledge of the academic literature. The white paper topics selected were: (1) the economic impacts of bicycle and pedestrian transportation; (2) the effectiveness of Safe Routes to School programs and other approaches to creating safe, healthy transportation options for children; (3) the effectiveness of intersection safety treatments for bicycles; and (4) the mental health benefits of bicycling and walking.

Each white paper was written after an extensive database search on each topic. The papers describe the research findings, identify research gaps, and describe how the findings can be applied in practice. IBPI requested review of each white paper by two practitioners and two academic researchers in their respective fields. Papers also were reviewed by Principal Investigator (PI) Jennifer Dill. The papers are in process of final formatting for distribution via the IBPI website at http://ibpi.usp.pdx.edu/research.php. IBPI will also make requests to partner institutions and agencies to make the papers or links available on their websites. 


\subsection{OUTCOME AND RESULTS}

The web-based activities funded by this grant have increased and improved the dissemination of research that is relevant to practitioners involved with bicycle and pedestrian transportation. Both faculty and student research are now summarized and easily accessible via the web for easy downloading and use. In addition, the process of summarizing and reviewing the research and projects by the PIs has made them more aware of the website's existence and the potential for wider dissemination of research findings and application to practice.

The development and dissemination of the white papers has advanced understanding of the state of knowledge, including what is known and gaps in research, on the four topics examined. The findings from all four topics have important implications for future directions of both research and practice. The paper on the effectiveness of Safe Routes to School programs identified both areas of success of these programs, and the areas where more rigorous evaluation is needed to determine program effectiveness. The research on intersection design for bicycle safety found an over paucity of data on the safety and effectiveness of several facility designs, at least within the U.S. Findings from the review of knowledge on the economic benefits of bicycling illustrated both the potential for bicycling to generate a positive economic impact and the need for more research to substantiate the initial findings. The review of mental health benefits of bicycling and walking found that limited research exists on the impact of bicycling and walking specifically on mental health, although as a means of physical activity these activities indirectly have a positive impact of mental health.

At the same time, activities undertaken with matching funds, including professional development, outreach, and curriculum development, have increased awareness and dialogue among decision-makers, professionals and university students of innovations in bicycle and pedestrian transportation and what is needed to advance bicycle and pedestrian transportation locally and nationally. For example, nearly 100 practitioners have participated in the four IBPIsponsored professional development workshops in the past year. These workshops, focusing on planning, design and engineering issues for on- and off-street bicycle, pedestrian and trail facilities, are part of IBPI's ongoing effort to equip professionals with current knowledge on practice and research findings on bicycle and pedestrian transportation. As an added benefit, these workshops have generated dialogue among participants and instructors. 


\subsection{FURTHER ACTIVITIES}

This project provides a strong base to expand IBPI's technology transfer and information-sharing activities. We will continue to update and improve the website's offerings and resources by identifying new information to share and responding to professional, academic and user suggestions. In addition, we will update the CTS seminar listings, research digests and student work summaries each term as they become available, and expand links to resources as we learn about them. As the website's information base increases, it will become an even better tool for sharing resources and promoting technology transfer from research to practice.

The white papers will serve as a springboard for future projects and research, many of which are already underway. The paper on the effectiveness of Safe Routes to School is already being used as IBPI begins working with the Portland Office of Transportation to conduct an evaluation of their Safer Routes to School program. The review of relevant literature will assist PDOT staff in designing an evaluation program that will increase the effectiveness of their program and identify elements to improve or build upon. The paper on intersection safety for bicycle facilities is providing a scholarly basis for a current research proposal by Dr. Chris Monsere, Dr. Jennifer Dill and the City of Portland to evaluate the city's recently-installed bicycle boxes. The paper on the economic benefits of bicycling is providing a foundation of existing knowledge that will be used on a collaboration among IBPI, Alta Planning + Design, the City of Portland and other partners to update and expand the City's 2006 report on this topic. The research on the mental health benefits of walking and bicycling has identified some critical gaps in research that we expect to use as we develop a research agenda linking bicycling, walking and public health for future projects. In addition, IBPI will consider submitting papers to practice and academic publications and conferences, further extending the knowledge gained through this research.

In summary, the activities funded by this OTREC grant have given IBPI a solid foundation in its work to advance research and practice on bicycle and pedestrian transportation by serving as a resource for information and conducting relevant research that is relevant and accessible to practitioners. 


\subsection{REFERENCES}

Federal Highway Administration (October, 2004). National Bicycling and Walking Study. Washington, D.C.: Federal Highway Administration. 
P.O. Box 751

Portland, OR 97207

www.otrec.us

OTREC is dedicated to stimulating and conducting collaborative multi-disciplinary research on multi-modal surface transportation issues, educating a diverse array of current practitioners and future leaders in the transportation field, and encouraging implementation of relevant research results. 